\title{
ANALISIS KEMAMPUAN PENALARAN MATEMATIS SISWA SMP PADA MATERI SEGITIGA DAN SEGIEMPAT
}

\author{
Anggie Munthia Safitri ${ }^{1}$, Euis Eti Rohaeti ${ }^{2}$, M. Afrilianto ${ }^{3}$ \\ 1,2, 3 IKIP Siliwangi, J1. Terusan Jendral Sudirman Cimahi 40526 \\ ${ }^{1}$ anggiemunthias@gmail.com, ${ }^{2}$ e2rht@ikipsiliwangi.ac.id,3 muhammadafrilianto@ikipsiliwangi.ac.id
}

\begin{abstract}
The aim of this research is to know the difficulties of reasoning ability include: (1) ability to give explanation related to Triangle and Segiempat using model, fact, nature, and relationship, (2) student ability to estimate answer and solution process of question given, (3) ) the ability of students to use patterns and relationships to analyze problems in Triangle and Quadrilateral, (4) ability to draw conclusions from every problem that exist both orally and in writing. The method used in this study by using qualitative methods. Population taken in this research is a student of SMP Negeri 1 Ngamprah class VII. Based on the research result, the average score of students' mathematical reasoning ability on triangle and quadrilateral material is $47 \%$. Students who are able to determine the area and circumference of the flat wake tested in the solution of mathematical reasoning is $35 \%$. While the number of students who are able to calculate the pattern $n$ as much as $20 \%$. Based on the data, it is concluded that there are students 'reasoning difficulties and students' mathematical reasoning ability at SMPN 1 Ngamprah is still low.
\end{abstract}

Keywords: Mathematical Reasoning

\begin{abstract}
Abstrak
Penelitian ini bertujuan untuk mengetahui kesulitan kemampuan penalaran meliputi: (1) kemampuan memberikan penjelasan yang berhubungan dengan Segitiga dan Segiempat menggunakan model, fakta, sifat - sifat dan hubungan, (2) kemampuan siswa memperkirakan jawaban dan proses solusi dari pertanyaan yang diberikan, (3) kemampuan siswa dapat menggunakan pola dan hubungan untuk menganalisis permasalahan dalam Segitiga dan Segiempat, (4) kemampuan untuk menarik kesimpulan dari setiap persoalan yang ada baik secara lisan maupun tulisan. Metode yang digunakan dalam penelitian ini dengan menggunakan metode kualitatif. Populasi yang di ambil dalam penelitian ini yaitu siswa SMP Negeri 1 Ngamprah kelas VII. Berdasarkan hasil penelitian bahwa nilai rata - rata kemampuan penalaran matematis siswa pada materi segitiga dan segiempat adalah $47 \%$. Siswa yang mampu menentukan luas dan keliling bangun datar yang diujikan dalam penyelesaian soal penalaran matematis adalah $35 \%$. Sedangkan banyaknya siswa yang mampu menghitung pola ke $-\mathrm{n}$ sebanyak $20 \%$. Berdasarkan data tersebut, disimpulkan bahwa terdapat kesulitan bernalar siswa dan kemampuan penalaran matematis siswa di SMPN 1 Ngamprah masih tergolong rendah.
\end{abstract}

Kata Kunci: Penalaran Matematis

How to cite: Safitri, A.M., Rohaeti, E.E., \& Afrilianto, M. (2018). Analisis Kemampuan Penalaran Matematis Siswa SMP pada Materi Segitiga dan Segiempat. JPMI - Jurnal Pembelajaran Matematika Inovatif, 1 (4), 759-764.

\section{PENDAHULUAN}

Pendidikan dewasa ini mendapatkan perhatian secara komprehensif dalam upaya peningkatan mutunya. Peningkatan mutu pendidikan berarti pula peningkatan kualitas sumber daya manusia. Untuk itu perlu dilakukan upaya pembaruan dalam bidang pendidikan dari waktu ke waktu secara berkesinambungan (Hendriana \& Afrilianto, 2014) Menurut Mulyasa 
(Hendriana \& Afrilianto, 2014) dalam rangka mencerdaskan kehidupan bangsa, maka peningkatan mutu pendidikan suatu hal yang sangat penting bagi pembangunan berkelanjutan di segala aspek kehidupan manusia. Untuk mencapai tujuan pendidikan, lembaga pendidikan seperti sekolah, keluarga, dan masyarakat sangat menentukan dalam mengembangkan pribadi anak. Aktivitas yang diterapkan dalam pembelajaran di sekolah adalah aktivitas yang membutuhkan keterlibatan aktif dari para siswa. Salah satu tujuan pembelajaran adalah untuk meningkatkan kualitas pendidikan di Indonesia pada mata pelajaran matematika dimana salah satu kemampuan yang harus dimiliki siswa yaitu kemampuan penalaran matematis.

Menurut Roesdiana, (2016) "Kemampuan penalaran adalah suatu proses atau aktivitas berpikir untuk menarik kesimpulan atau membuat pernyataan baru yang benar berdasarkan pada pernyataan yang telah dibuktikan". Kemampuan bernalar tidak hanya dibutuhkan oleh setiap manusia disaat memecahkan masalah atau menentukan keputusan.

Salah satu yang ditemukan adalah siswa kurang memiliki kemampuan memahami dan mengenali konsep-konsep dasar matematika dan siswa kurang menggunakan daya nalarnya dalam menyelesaikan persoalan matematika yang diberikan (Wahyudin, 2008)

Berdasarkan narasumber yaitu salah satu guru matematika kelas VII SMP Negeri 1 Ngamprah, sebagian besar siswa mengalami kesulitan untuk memahami materi yang diberikan dengan menggunakan daya nalarnya. Mereka cenderung tidak suka atau kesulitan menggunakan kemampuan bernalar nya untuk menyelesaikan permasalahan matematika yang diberikan guru saat pembelajaran berlangsung. Alih - alih menurut siswa matematika itu sulit, banyak menggunakan rumus dan akhirnya siswa cenderung menghapalkan rumus yang diberikan oleh guru tanpa memahami dan menggunakan daya nalarnya dalam pembelajaran matematika.

\section{METODE}

Penelitian ini menggunakan penelitian deskriptif dimana penelitian diambil di salah satu sekolah SMP Ngamprah. Pada penelitian ini dilakukan melalui tes tertulis dengan bentuk soal uraian yang telah teruji validitas, daya pembeda dan indeks kesukarannya. Prosedur penelitian ini dilakukan dalam 3 tahapan, diantaranya: 1) tahap persiapan, 2) tahap pelaksanaan, 3) tahap evaluasi. Pada tahap persiapan diantaranya: 1) mengidentifikasi masalah yang akan diteliti, 2) menyusun instrumen penelitian berupa soal. Dalam tahap pelaksanaan langkah langkahnya adalah: melakukan tes kepada siswa. dan tahap akhir dalam penelitian adalah tahap evaluasi dengan langkah - langkah diantaranya: 1) mengumpulkan data hasil penelitian, 2) mengolah dan menganalisis hasil tes, 3) menyimpulkan rumusan masalah dan 4) menyusun laporan hasil penelitian.

\section{HASIL DAN PEMBAHASAN}

\section{Hasil}

Penelitian ini dilakukan untuk mengetahui kesulitan kemampuan penalaran matematis siswa kelas VII di SMPN 1 Ngamprah pada materi segitiga dan segiempat. Pengambilan data dilakukan melalui tes tertulis selama penelitian berlangsung. Data hasil penelitian ini diperoleh berdasarkan hasil tes kemampuan penalaran matematis siswa pada materi segitiga dan segiempat. 
Banyaknya soal yang diujikan sebanyak 5 soal dengan sampel siswa kelas VII di SMPN 1 Ngamprah. Pada penelitian ini bertujuan mengetahui rata - rata siswa yang mampu menjawab secara rinci dengan menunjukkan rumus hitung luas atau keliling bangun pola ke-n. Dari hasil analisis terlihat kesulitan kemampuan penalaran matematis siswa pada materi segitiga dan segiempat khususnya dalam menghitung luas dan keliling berdasarkan soal yang diujikan.

Tabel 1. Persentase Hasil Belajar Siswa

\begin{tabular}{cccccc}
\hline \multirow{2}{*}{ Sampel } & \multicolumn{5}{c}{ Jumlah Skor } \\
\cline { 2 - 6 } & 1 & 2 & 3 & 4 & 5 \\
\hline A1 & 3 & 3 & 2 & 0 & 1 \\
A2 & 3 & 3 & 1 & 1 & 3 \\
A3 & 2 & 2 & 1 & 0 & 2 \\
A4 & 3 & 2 & 1 & 1 & 2 \\
A5 & 2 & 2 & 1 & 2 & 2 \\
\hline Jumlah & 13 & 12 & 7 & 4 & 12 \\
\hline Persentase & $65 \%$ & $60 \%$ & $35 \%$ & $20 \%$ & $55 \%$ \\
\hline
\end{tabular}

\section{Pembahasan}

Berdasarkan data Tabel 1, menunjukkan bahwa instrumen soal nomor 1, 2 dan 5 sudah memenuhi ketercapaian indikator kemampuan penalaran. Sedangkan nomor 3 dan 4 belum memenuhi ketercapaian indikator. Dengan tes sebanyak 5 soal yang menggunakan kemampuan penalaran pada pola, sifat atau melakukan manipulasi matematika dalam membuat generalisasi, menyusun bukti, atau menjelaskan gagasan dan pernyataan matematika. Siswa banyak yang memperkirakan jawaban dan proses solusi tanpa melihat permasalahan yang ada sesuai indikator penalaran (Rosyana \& Sari, 2016). Sebagian besar siswa melakukan penyelesaian masalahnya dengan kemampuan penalaran imitatif yaitu tipe penalaran yang dalam mencari solusi suatu permasalahan matematika dilakukan dengan cara meniru solusi seperti contoh soal maupun latihan yang terdapat pada buku latihan seperti langkah-langkah dari solusi suatu permasalahan, tetapi terdapat pula siswa yang memiliki kemampuan penalaran kreatif yaitu proses penyelesaian masalah yang dilakukan siswa dengan memperhatikan aspek kebaruan (Hidayat, 2017). Presentase rata-rata kemampuan penalaran matematis siswa yaitu $47 \%$. Hal tersebut menunjukkan bahwa kemampuan penalaran siswa SMP pada materi segitiga dan segiempat masih tergolong rendah.

Adapun analisis data hasil pengerjaan siswa sebagai berikut:

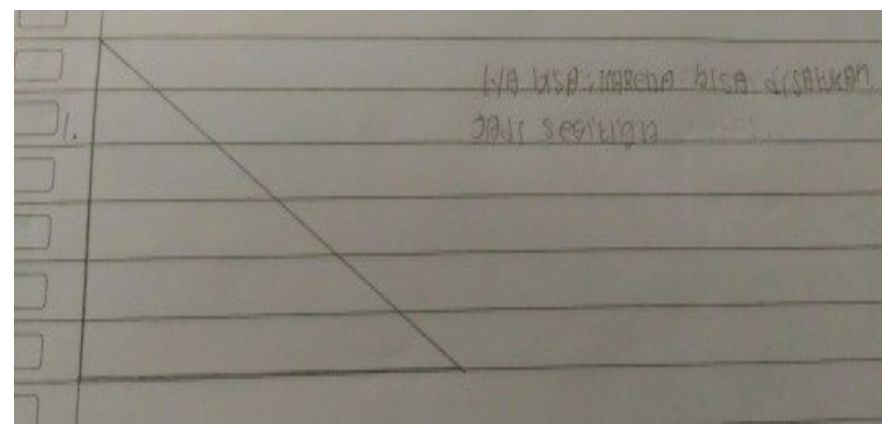

Gambar 1. Jawaban Siswa Nomor 1 
Dari gambar 1 siswa hampir tepat dalam menyelesaikan permasalahan matematika yang ditanyakan hanya saja dalam penyelesaian tersebut siswa tidak menggunakan teori yang baku untuk membuktikan jawabannya benar-benar berbentuk bangun datar segitiga.

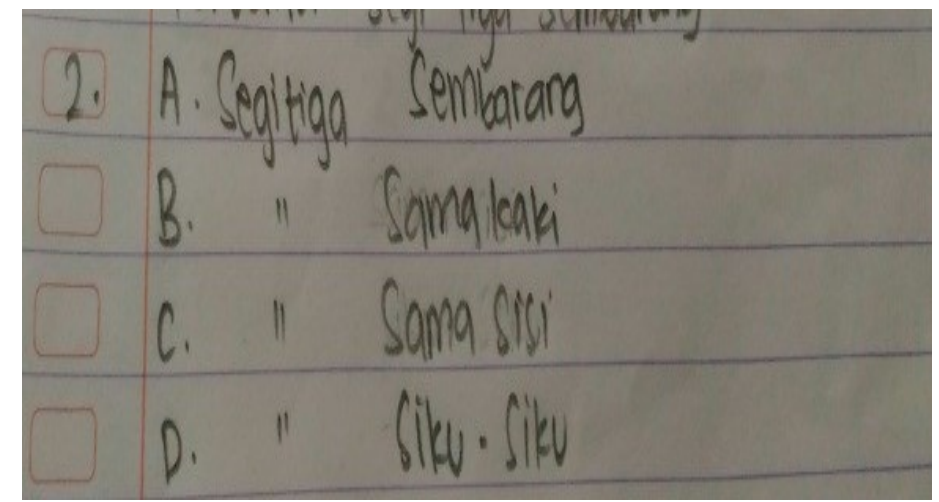

Gambar 2. Jawaban Siswa Nomor 2

Dari gambar 2 siswa menjawab dengan tepat dan soal tidak dianggap oleh siswa terlalu sulit untuk dikerjakan.

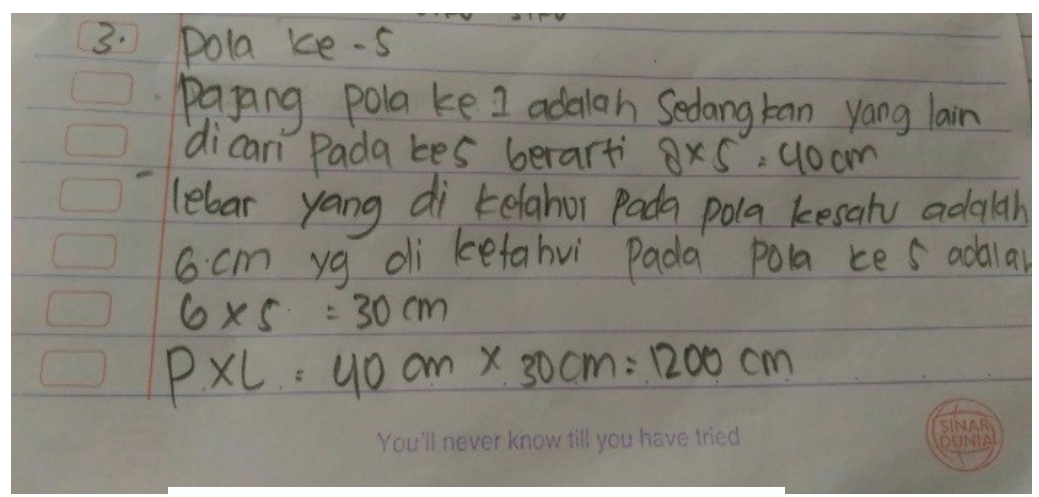

Gambar 3. Jawaban Siswa Nomor 3

Dari gambar 3 menunjukkan siswa menjabarkan apa yang diketahui dan yang ditanyakan, tetapi siswa belum bisa membedakan antara mencari keliling bangun datar persegi dan persegi panjang.

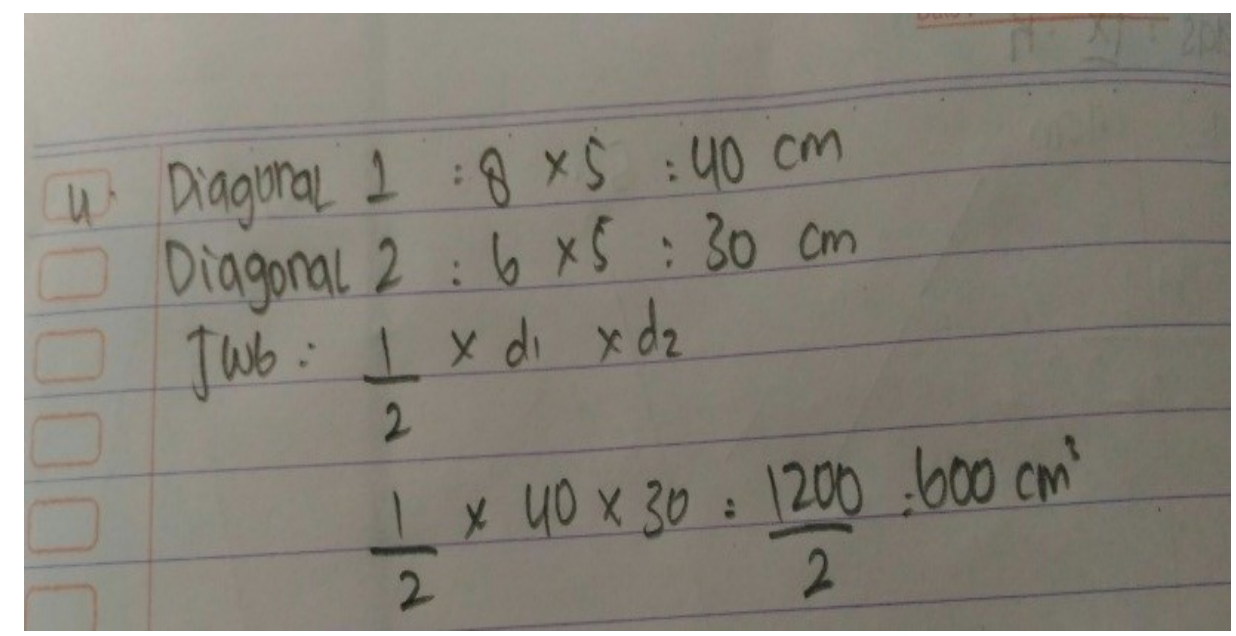

Gambar 4. Jawaban Siswa Nomor 4 
Dari gambar 4 diatas, terlihat kesulitan siswa saat menentukan panjang sisi belah ketupat pada pola ke-1. Siswa tidak memahami bahwa untuk menentukan panjang sisi-sisinya harus menggunakan rumus phytagoras. Sehingga siswa tidak dapat menyelesaikan keliling bangun pola ke-1 tersebut.

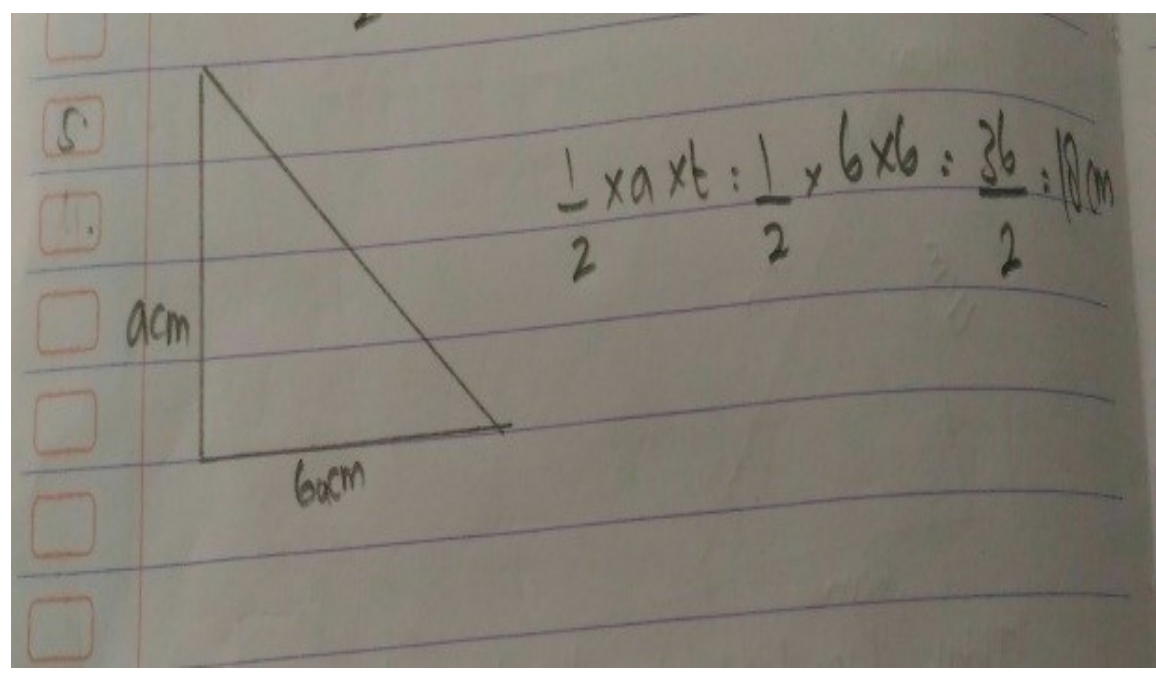

Gambar 5. Jawaban Siswa Nomor 5

Dari gambar 5 jawaban yang diberikan untuk menentukan pola yang ditemukan tepat, tetapi dalam mencari luas segitiga terjadi kesalahan dalam penggunaan rumus dan unsur yang diketahui.

\section{KESIMPULAN}

Berdasarkan hasil analisis data dari soal - soal yang diberikan, bahwa rata - rata kemampuan bernalar siswa pada materi segitiga dan segiempat adalah $47 \%$. Siswa yang mampu menentukan luas atau keliling bangun datar yang diujikan dalam penyelesaian soal penalaran matematis adalah $35 \%$. Banyaknya siswa yang mampu menghitung pola ke-n sebanyak 20 $\%$. Berdasarkan data tersebut, disimpulkan bahwa terdapat kesulitan bernalar siswa dan kemampuan penalaran matematis siswa masih tergolong rendah..

\section{DAFTAR PUSTAKA}

Hendriana, H., \& Afrilianto, M. (2014). Panduan bagi Guru, Penelitian Tindakan Kelas Suatu Karya Tulis Ilmiah. Bandung: PT Refika Aditama.

Hidayat, W. (2017). Adversity Quotient dan Penalaran Kreatif Matematis Siswa SMA dalam Pembelajaran Argument Driven Inquiry pada Materi Turunan Fungsi. KALAMATIKA Jurnal Pendidikan Matematika, 2(1), 15-28.

Roesdiana, L. (2016). Pembelajaran dengan pendekatan metaphorical thinking untuk mengembangkan kemampuan komunikasi dan penalaran matematis siswa. Judika (Jurnal Pendidikan Unsika), 4(2).

Rosyana, T., \& Sari, I. P. (2016). Penerapan Aktivitas Quick On The Draw Melalui Pendekatan Thinking Aloud Pair Problem Solving Untuk Meningkatkan Kemampuan 
764 Safitri, Rohaeti\& Afrilianto, Analisis Kemampuan Penalaran Matematis Siswa SMP

Komunikasi Dan Penalaran Matematis Siswa Ma. P2M STKIP Siliwangi, 2(2), 192-202. Wahyudin, P. (2008). Pembelajaran dan Model-Model Pembelajaran. Diktat Kuliah. 